\title{
Demethoxycurcumin Suppresses Migration and Invasion of Human Cervical Cancer HeLa Cells via Inhibition of NF-kB Pathways
}

\author{
CHIN-CHUNG LIN ${ }^{1,2}$, CHAO-LIN KUO $^{3}$, YI-PING HUANG ${ }^{4}$, CHENG-YEN CHEN $^{5}$, \\ MING-JIE HSU ${ }^{5}$, YUNG LIN CHU ${ }^{6}$, FU-SHIN $\mathrm{CHUEH}^{7}$ and JING-GUNG CHUNG ${ }^{5,8}$ \\ ${ }^{1}$ Departments of Chinese Medicine, Feng-Yuan Hospital, \\ Ministry of Health and Welfare, Executive Yuan, Taichung, Taiwan, R.O.C.; \\ ${ }^{2}$ General Education Center, Central Taiwan University of Science and Technology, Taichung, Taiwan, R.O.C.; \\ ${ }^{3}$ Department of Chinese Pharmaceutical Sciences and Chinese Medicine Resources, \\ China Medical University, Taichung, Taiwan, R.O.C.; \\ ${ }^{4}$ Department of Physiology, China Medical University, Taichung, Taiwan, R.O.C.; \\ ${ }^{5}$ Department of Biological Science and Technology, China Medical University, Taichung, Taiwan, R.O.C.; \\ ${ }^{6}$ International Master's Degree Program in Food Science, International College, National \\ Pingtung University of Science and Technology, Pingtung, Taiwan, R.O.C.; \\ ${ }^{7}$ Department of Food Nutrition and Health Biotechnology, Asia University, Taichung, Taiwan, R.O.C.; \\ ${ }^{8}$ Department of Biotechnology, Asia University, Taichung, Taiwan, R.O.C.
}

\begin{abstract}
Background/Aim: Demethoxycurcumin (DMC), one of the curcuminoids present in turmeric, has been shown to induce cell death in many human cancer cell lines, however, there has not been any investigation on whether DMC inhibits metastatic activity in human cervical cancer cells in vitro. In the present study, DMC at 2.5-15 $\mu M$ decreased cell number, thus, we used $I C_{20}(7.5 \mu M)$ for further investigation of its anti-metastatic activity in human cervical cancer HeLa cells. Materials and Methods: The wound healing, migration, invasion, zymography, and western blotting assays were used to investigate the effects of DMC on HeLa cells. Results: The wound healing assay was used to show that DMC suppressed cell movement of HeLa cells. Furthermore, the trans-well chamber assay was used to show that DMC suppressed HeLa cell migration and invasion. Gelatin zymography assay did not show any
\end{abstract}

Correspondence to: Prof. Jing-Gung Chung, Department of Biological Science and Technology, China Medical University, No 91, HsuehShih Road, Taichung, Taiwan, R.O.C. Tel: +8864 22053366, ext. 8000, Fax: +886 4 22053764, e-mail: jgchung@mail.cmu.edu.tw; Prof. Fu-Shin Chueh, Department of Food Nutrition and Health Biotechnology, Asia University, No 500, Liufeng Road, Wufeng, Taichung, Taiwan, R.O.C. Tel: +886 423323456 , ext. 1848, Fax: +886 4 23321206, e-mail: fushin@asia.edu.tw

Key Words: Demethoxycurcumin (DMC), migration, invasion, NF-kB, p65, HeLa cells. significant effects of DMC on the gelatinolytic activity (MMP-2 and -9) in conditioned media of HeLa cells treated by DMC. Western blotting showed that DMC significantly reduced protein levels of GRB2, MMP-2, ERK1/2, Ncadherin and Ras but increased the levels of E-cadherin and $N F-k B$ in HeLa cells. Confocal laser microscopy indicated that DMC increased $N F-K B$ in HeLa cells confirming the results from Western blotting. Conclusion: DMC may be used as a novel anti-metastatic agent for the treatment of human cervical cancer in the future.

Uterine cervical cancer has been recognized to be the third most common cancer and the fourth cause of cancer-related death in females worldwide (1) and the persistent infection with oncogenic strains of human papillomavirus is a major risk factor for this disease (2). Other causative factors include carcinogenic chemicals and radiation. Also, germline mutations, such as EGFR T790MI appear to have an increased risk of lung cancer (3). In Taiwan, cervical cancer is the 8th common cancer in females based on a report in 2016 from the Department of Health, Taiwan, Republic of China (R.O.C.) which indicated that 4.1 individuals per 100,000 die annually from cervical cancer (4). Recently, Khazaei et al., 2017 have shown that cervical cancer is the second most common cancer and the third leading cause of cancer-related death among women worldwide (5). That means cervical cancer has increased since few years ago worldwide. The treatment of cervical cancer includes 
surgery, chemotherapy and radiotherapy or the combination of surgery and chemotherapy or chemotherapy and radiotherapy etc. However, the possibilities of remission, relapse and metastasis are still substantial. Therefore, the strategy for inhibiting cancer cell metastasis is also important for treating cervical cancer.

Cancer metastasis involves a series of events like cancer cell detachment, proteolysis, penetration, intravasation, and invasion for moving to new tissue or organ (6). Cancer invasion and the metastasis process require degradation of the extracellular matrix (ECM) and basement membrane (BM) (7). The Matrix metalloproteinases (MMPs) (Zndependent proteinases), degrade all kinds of ECM proteins, thus, MMPs are involved in the progress of cancer cells invasion and migration. MMP-9 and MMP-2 are Type IV collagenases that degrade basement membrane collagen (8). The increased MMP-2 and MMP-9 activities and expression levels are correlated with reduced survival and poor prognosis in human malignancies $(9,10)$. It has been suggested that application of MMPs inhibitors could adequately treat metastasis $(11,12)$.

Natural products have been widely used to treat and prevent cancers and some of the traditional medicines and phytochemicals have been used to control the invasiveness of many metastatic cancer cell lines $(13,14)$ and these compounds may act through multiple pathways for interfering the cell invasion and metastasis (15). Curcumin was extracted from the Curcuma longa rhizome and it is the main active ingredient of turmeric, and has been widely used by consumers in Asian countries especial in India and China (16, 17). Curcumin is easily degraded in vitro and in vivo. Demethoxycurcumin (DMC) is lacking a methoxy group attached to a benzene ring in curcumin. Thus, it is a derivative of curcumin that presents similar biological properties as curcumin. However, it has been reported to be, chemically, more stable than curcumin (18). Several studies have shown that DMC is cytotoxic in many human cancer cells such as prostate cancer (19), lung cancer (20), and skin cancer cells (21). Although DMC has been shown to present antioxidant, anti-inflammatory and anti-proliferative activities $(22,23)$, there are no reports on its effects on metastasis in cancer cells. In the present study, the effects of DMC on the cell migration and invasion in human cervical cancer HeLa cells in vitro were investigated. Results indicated that DMC inhibited cancer cell migration and invasion through the inhibitions of NF-kB, MMP-2 and -9 pathways.

\section{Materials and Methods}

Chemicals and reagents. Demethoxycurcumin (DMC), dimethyl sulfoxide (DMSO) and propidium iodide (PI) were obtained from Sigma Chemical Co. (St. Louis, Missouri, USA). DMEM medium, fetal bovine serum (FBS), L-glutamine and antibiotics (penicillinstreptomycin) were purchased from $\mathrm{GIBCO}^{\circledR} /$ Invitrogen Life
Technologies (Grand Island, NY, USA). Primary antibodies and secondary antibodies were obtained from Cell Signaling (St. Louis, MO, USA). Polyvinylidene difluoride (PVDF) membrane was obtained from Millipore (Temecula, CA, USA).

Cell culture. HeLa human cervical cancer cell line was purchased from the Food Industry Research and Development Institute (Hsinchu, Taiwan). Cells were cultured in DMEM medium containing 10\% FBS, 100 units $/ \mathrm{ml}$ penicillin and $100 \mu \mathrm{g} / \mathrm{ml}$ streptomycin in a $75 \mathrm{~cm}^{2}$ tissue culture flasks under humidified atmosphere of $5 \% \mathrm{CO}_{2}$ at $37^{\circ} \mathrm{C}(24,25)$.

Cell's viability assays. HeLa cells were placed in 12-well plates with DMEM medium for $24 \mathrm{~h}$ and were incubated with DMC at final concentrations $(0,2.5,5,7.5,10$ and $15 \mu \mathrm{M})$ or $0.5 \%$ DMSO as a vehicle control for $48 \mathrm{~h}$. After incubation, cells were collected, counted and stained with PI $(5 \mu \mathrm{g} / \mathrm{ml})$ to measure the total cell viability by flow cytometry (Becton-Dickinson, San Jose, California, USA) as previously described $(26,27)$.

Wound healing Assay. HeLa cells $\left(5 \times 10^{5}\right.$ cells/well) maintained in 6 -well plates were grown to complete confluency. Cell monolayers were scraped using a sterile yellow micropipette tip and washed with PBS three times. Cells were then cultured in DMEM medium containing 0 and $7.5 \mu \mathrm{M}$ of DMC for 24 and $48 \mathrm{~h}$. Cells were examined and photographed using an inverted microscope as described previously $(25,28)$.

Invasion and migration assay. The measurements of HeLa cell migration and invasion were performed by using Matrigel-coated transwell cell culture chambers $(8 \mu \mathrm{m}$ pore size $)$ as described previously (28). Briefly, HeLa cells $\left(5 \times 10^{5}\right.$ cells/well) were maintained in 12-well plates and were incubated with 0 and $7.5 \mu \mathrm{M}$ of DMC for 24 and $48 \mathrm{~h}$. For measurement of cell migration, cells were placed on the top of well with membrane coated with collagen and then incubated with DMC. The non-invaded cells were removed from the upper surface of the membrane and the invaded cells on the lower surface of the membrane were fixed with $4 \%$ cold formaldehyde, stained with $0.1 \%$ crystal violet and then were photographed. The invaded cells in the chamber were counted. For the measurement of cell invasion, the same migration assay was used but the membrane was coated with matrigel as described previously (28-30).

Gelatin zymography assay. Gelatin zymography was used to measure the activities of MMP-2 and -9. Briefly, HeLa cells $\left(5 \times 10^{5}\right.$ cells/well) were maintained in 6-well culture plates for about $80 \%$ confluency and serum-free medium with DMC was added to cells for 12,24 and $48 \mathrm{~h}$. After incubation, the conditioned medium was collected, and $12 \mu 1$ of medium was electrophoresis on $10 \%$ SDSPAGE containing $0.2 \%$ gelatin. The gel was washed and was soaked in substrate buffer $\left(50 \mathrm{mM}\right.$ Tris $\mathrm{HCl}, 5 \mathrm{mM} \mathrm{CaCl}_{2}, 0.02 \% \mathrm{NaN}_{3}$ and $1 \%$ triton $\mathrm{X}-100, \mathrm{pH} 8.0$ ) while shaking for $18 \mathrm{~h}$ at $37^{\circ} \mathrm{C}$. A $0.2 \%$ Coomassie blue (Bio-Rad, Hercules, CA, USA) in $10 \%$ acetic acid and $50 \%$ methanol was used to stain the gels $(31,32)$ that were photographed on a light box. Proteolysis was detected as a white zone (MMP-2 and -9 gelatinolytic activities) in a dark blue field as described previously (33).

Western blotting assay. HeLa cells $\left(6 \times 10^{6}\right.$ cells $)$ in $10-\mathrm{cm}$ dish were incubated with 0 , and $7.5 \mu \mathrm{M}$ of DMC for 12,24 and $48 \mathrm{~h}$ and cells were collected and lysed in a lysis buffer [40 mM Tris- $\mathrm{HCl}(\mathrm{pH} 7.4)$, 
$10 \mathrm{mM}$ EDTA, $120 \mathrm{mM} \mathrm{NaCl}, 1 \mathrm{mM}$ dithiothreitol, $0.1 \%$ Nonide P-40] for measuring the total protein as described previously (28). A $30 \mu \mathrm{g}$ of protein was loaded on a SDS-PAGE gel and was transferred to a PVDF membrane. The membrane was blocked in $5 \%$ fat-free dry milk solution in PBS and probed with primary antibodies overnight at $4^{\circ} \mathrm{C}$. Then the membrane was incubated with a secondary antibody and developed using enhanced chemiluminescence (Millipore, Temecula, CA, USA) as described previously $(28,34)$.

Confocal laser microscopy assay. In this study, western blotting showed that treatment with DMC increased NF-kB expression in HeLa cells. Thus, this study was conducted in order to investigate whether or not DMC-induced inhibition of cell migration and invasion also involved nuclear translocation or expression of NF-kB HeLa cells were treated with $7.5 \mu \mathrm{M}$ of DMC for $48 \mathrm{~h}$ and were examined and photographed by Confocal laser microscopy systems as described previously (33).

Statistical analysis. All Data were expressed as means \pm SD from at least three experiments. Differences between groups were analyzed by one-way analysis of variance and Dunnett test for multiple comparisons (SigmaPlot for Windows version 12.0; Systat Software, Inc., San Jose, CA). Comparisons were made between groups of DMC-treated cells and untreated cells (control). Differences with $p<0.05\left(^{*}\right)$ were considered statistically significant.

\section{Results}

DMC decreases cell viability of HeLa cells. Cells were treated with DMC $(0,2.5,5,7.5,10$ and $15 \mu \mathrm{M})$ for $48 \mathrm{~h}$ and cell viability was assayed as described in Materials and Methods (Figure 1). Results indicated a significant dose-dependent reduction of living cells upon treatment of HeLa cells with DMC at 2.5-15 $\mu \mathrm{M}$ concentrations for $48 \mathrm{~h}$. Thus, 0 and $7.5 \mu \mathrm{M}$ [inhibitory concentration (IC) ${ }_{20}$ ] concentrations were selected for cell migration and invasion experiments.

DMC decreases cell mobility of HeLa cells. HeLa cells were grown in 6-well plates to complete confluency, scraped and incubated with medium containing 0 , and $7.5 \mu \mathrm{M}$ of DMC for 24 and $48 \mathrm{~h}$ (Figure 2). Results showed that the closure of scraped area in the DMC treated cells was slower than that of the control at both time points.

DMC inhibits cell migration and invasion of HeLa cells. The measurement of cell migration and invasion was performed by using Trans-well cell migration and invasion assays and the results are shown in Figure 3. DMC significantly $(p<0.05)$ inhibited cell migration by 29.56 and $68.65 \%$ at 24 and $48 \mathrm{~h}$, respectively (Figure $3 \mathrm{~A}$ ). DMC also inhibited cell invasion by $77.02 \%$ at $24 \mathrm{~h}$ compared to control cells (Figure 3B).

DMC inhibits the activities of MMP-2/-9 in HeLa cells. The gelatin zymography was performed to detect the gelatinolytic activity (MMP-2 and -9) in conditioned media of HeLa cells treated by DMC. HeLa cells were incubated with DMC (7.5

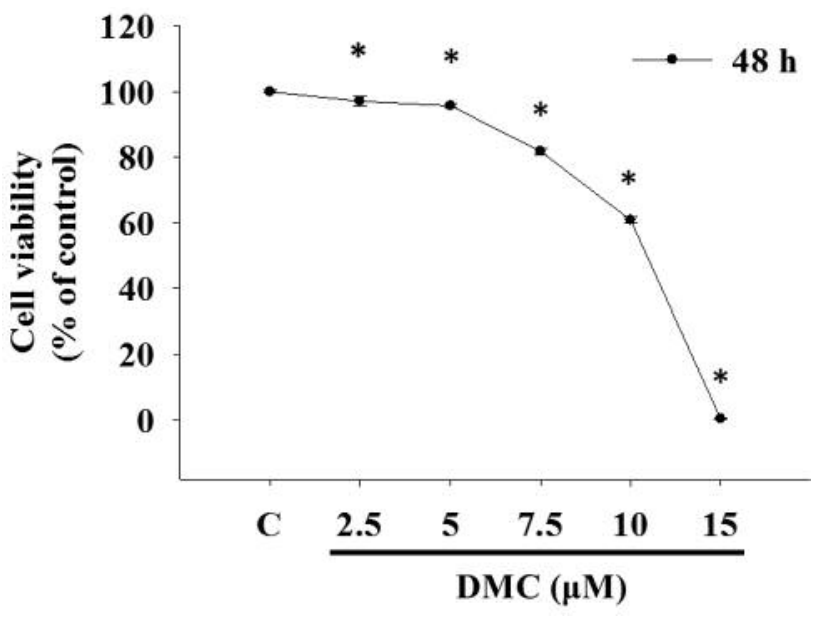

Figure 1. DMC decreased the cell viability of HeLa cells. HeLa cells were placed in 12-well plates with DMEM medium for $24 \mathrm{~h}$ and incubated with DMC at final concentrations of 0, 2.5, 5, 7.5, 10 and $15 \mu \mathrm{M}$ or $0.5 \%$ DMSO as a vehicle control for $48 \mathrm{~h}$. After incubation, cells were collected, counted and stained with PI $(5 \mu \mathrm{g} / \mathrm{ml})$ to measure the total cell viability by flow cytometry as described in Materials and Methods. $* p<0.05$, significant difference between DMC-treated groups and the control as analyzed by Dunnett test.

$\mu \mathrm{M})$ for 12,24 and $48 \mathrm{~h}$, and the gelatinolytic activity of MMP-2/-9 was assayed (Figure 4). Results indicated that DMC did not inhibit the gelatinolytic activity of MMP-2 and -9 at $12-48 \mathrm{~h}$ of treatment compared to the control $(0 \mathrm{~h})$.

DMC alters levels of proteins associated with migration and invasion of HeLa cells. In order to examine the mechanism by which DMC affects migration and invasion of HeLa cells, its effects on the levels of certain proteins was examined (Figure 5). DMC was found to significantly reduce protein levels of GRB2, Ras, Rho A, p-ERK1/2, ERK1/2 (Figure 5A), uPA, MMP-9, MMP-2 (Figure 5B), Snail (Figure 5C), $\mathrm{N}$-cadherin, $\beta$-catenin and Vimentin (Figure 5D), but increased the levels of TNF- $\alpha$, NF-kB (p50), NF-kB (p65) (Figure 5C) and E-cadherin (Figure 5D). Based on these observations, it is concluded that DMC inhibits cancer cell migration and invasion through inhibition of NF-kB, MMP2 and -9 pathways.

DMC affects nuclear translofcation of NF- $k B$ in HeLa cells. The effects of DMC on the translocation of NF-kB in HeLa cells was examined. Cells were incubated with or without $7.5 \mu \mathrm{M}$ of DMC for $24 \mathrm{~h}$ were stained by anti-NF-kB antibody and examined by confocal laser microscope and photographed (Figure 6). The results showed that DMC increased NF-kB expression in the cytoplasm and nucleus compared to control $(0 \mu \mathrm{M})$. These results were consistent with those obtained from western blotting. 
A

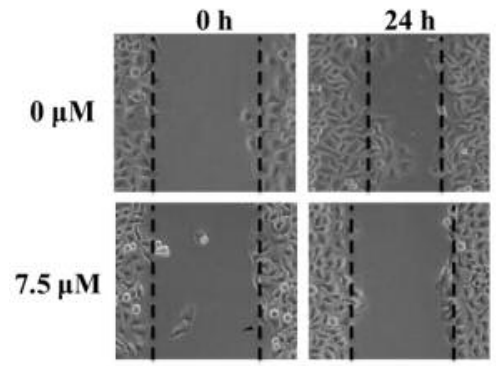

B

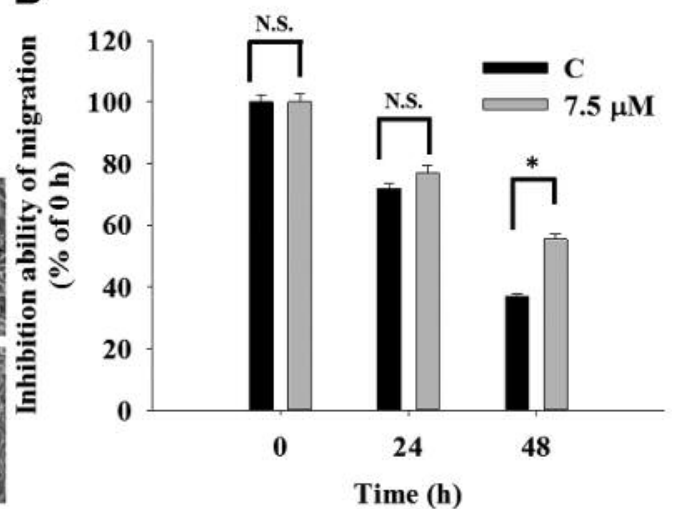

Figure 2. DMC decreased mobility of HeLa cells. HeLa cells were grown in 6-well plate until confluency and cell monolayers were scraped and incubated in medium containing 0 and $7.5 \mu M$ of DMC for 24 and 48 h. After incubation, closure of the gap generated by the scraping was assayed as described in Materials and Methods. (A) The representative figures for closures of scraped area; (B) The percentage of inhibition was calculated. ${ }^{*} p<0.05$, significant difference between DMC-treated groups and the control as analyzed by Dunnett test. N.S.: Not significant.

A

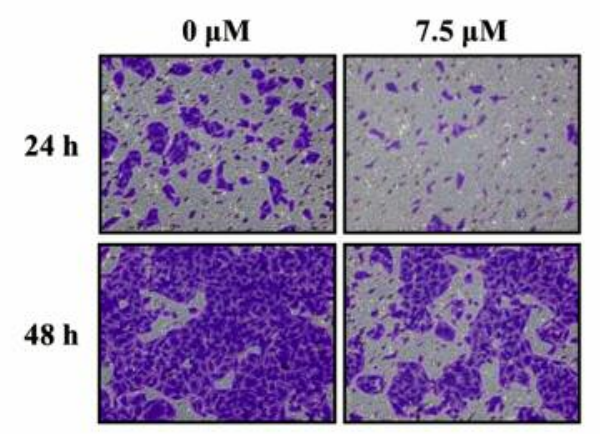

B

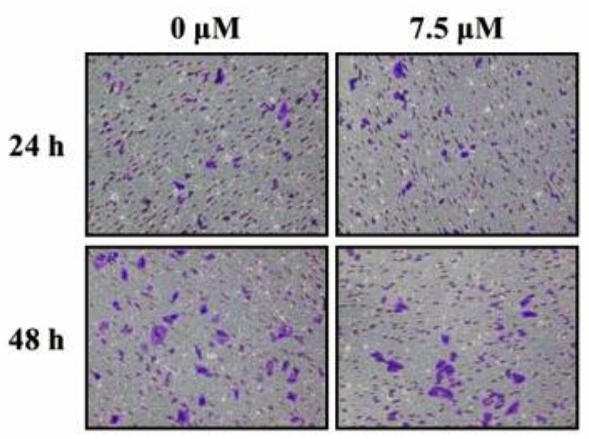

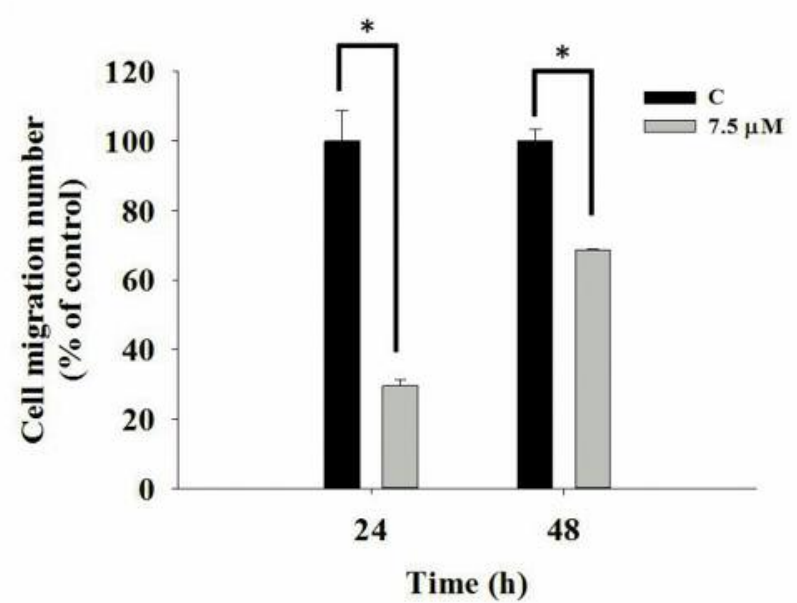

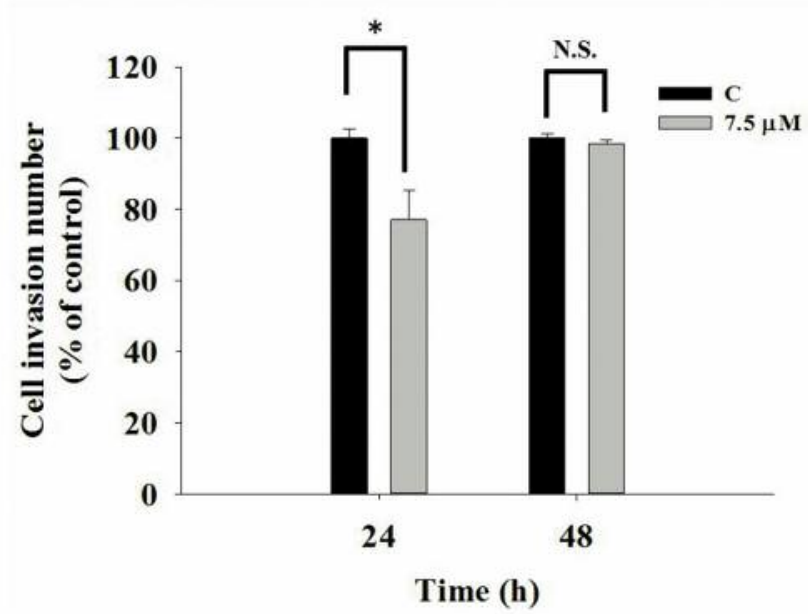

Figure 3. DMC inhibited the migration and invasion of HeLa cells. The measurement of cell migration and invasion was performed by using Transwell cell migration and invasion assays as described in Materials and Methods. (A) Transwell assays with collagen were performed to detect the migration activity. (B) Transwell assays with matrigel were performed to detect the invasion activity. ${ }^{*} p<0.05$, significant difference between DMCtreated groups and the control as analyzed by Dunnett test. N.S.: Not significant. 

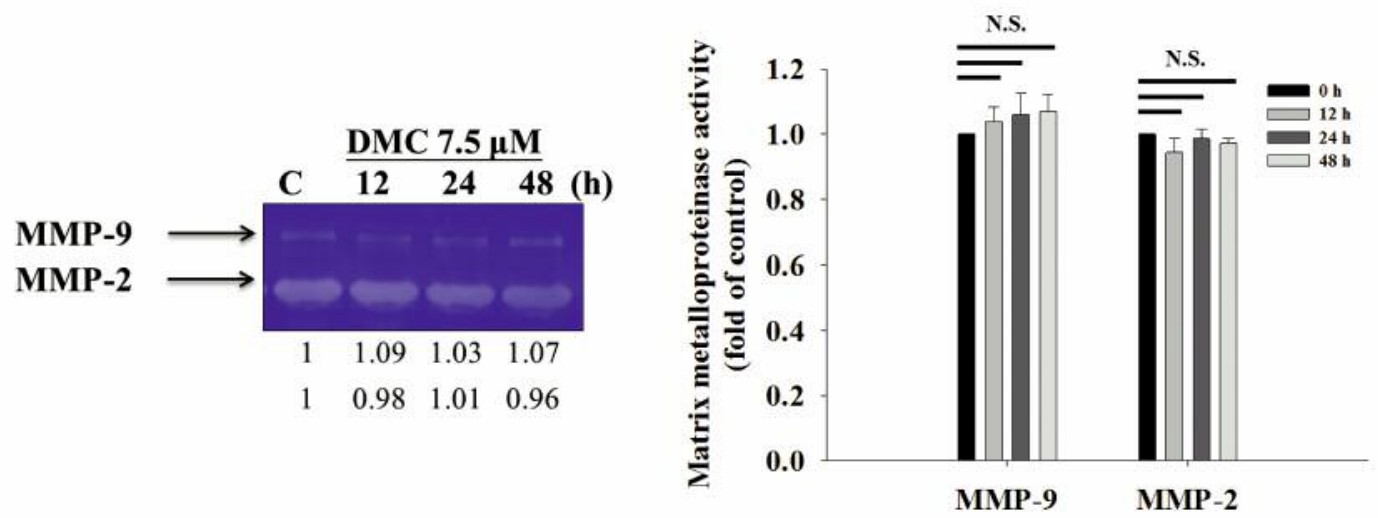

Figure 4. DMC did not inhibit the activity of MMP-2/-9 in HeLa cells. Gelatin zymography was performed to detect the MMP-2 and -9 gelatinolytic activity in conditioned media of HeLa cells treated by DMC. HeLa cells were incubated with DMC (7.5 $\mu M)$ for 12, 24 and 48 h, and the gelatinolytic activity of MMP-2/-9 was measured as described in Materials and Methods. N.S.: Not significant.

A
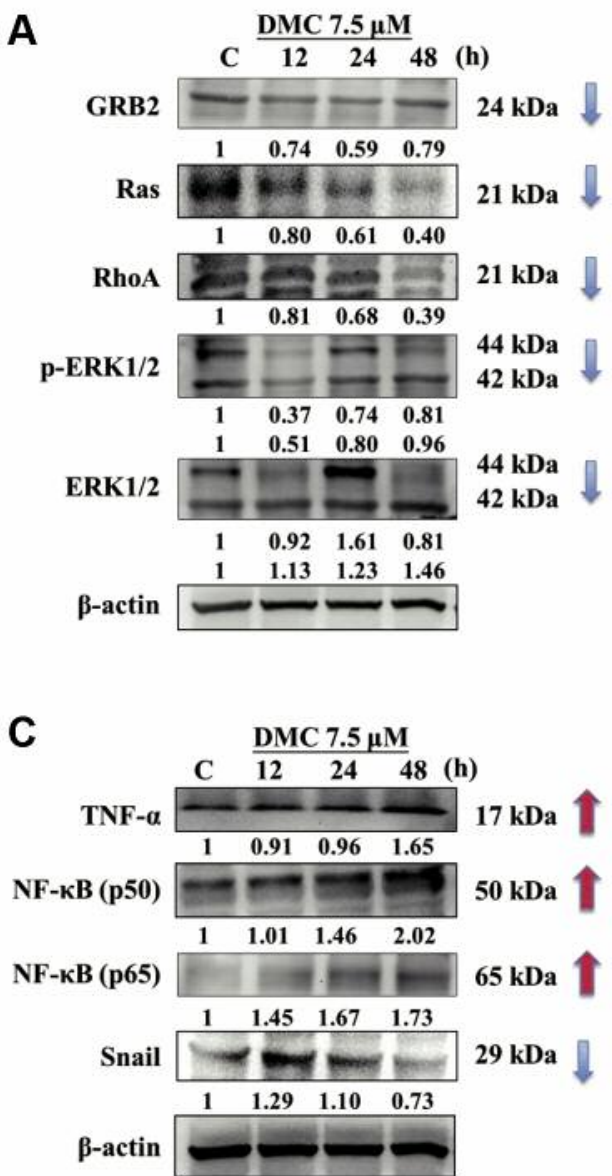
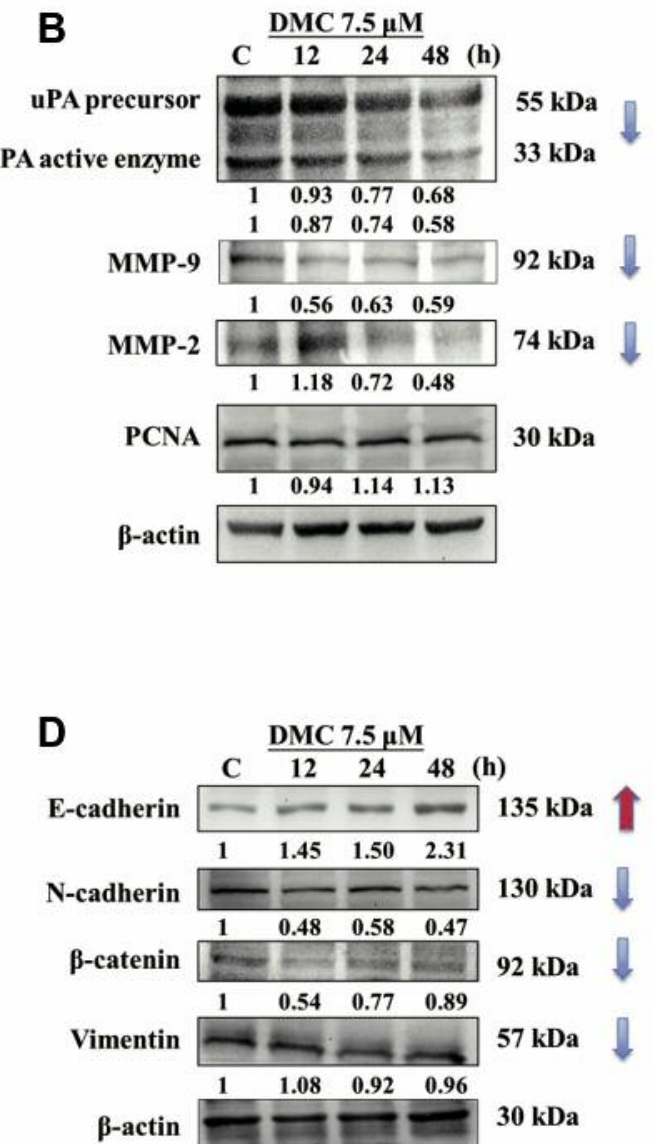

Figure 5. DMC alters levels of proteins associated with migration and invasion of HeLa cells. Cells were treated with 7.5 $\mu M$ of DMC for 12, 24 and $48 \mathrm{~h}$ and the levels of certain metastasis associated proteins were examined by western blotting as described in Materials and Methods. A: GRB2, Ras, Rho A, p-ERK1/2 and ERK1/2. B: uPA, MMP-9, MMP-2, PCNA. C: TNF- $\alpha, N F-k B(p 50), N F-k B$ (p65) and Snail. D: E-cadherin, $N$-cadherin, $\beta$-catenin and vimentin. 


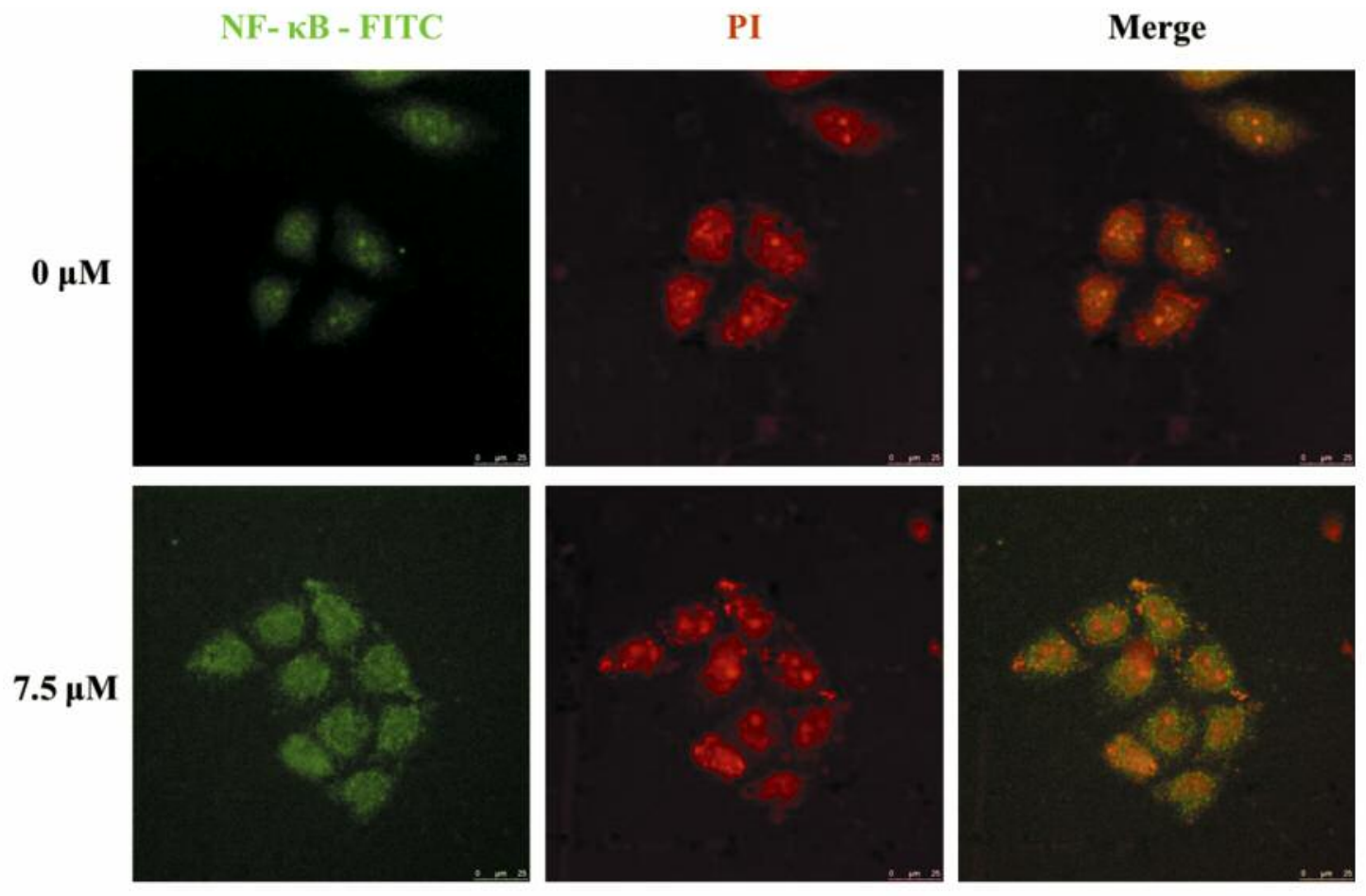

Figure 6. DMC affects the translocation of NF-kB HeLa cells. Cells were treated with $7.5 \mu M$ of DMC for 24 h and cells and stained by anti-NF-kB examined by a Leica TCS SP2 confocal laser microscope and photographed as described in Materials and Methods.

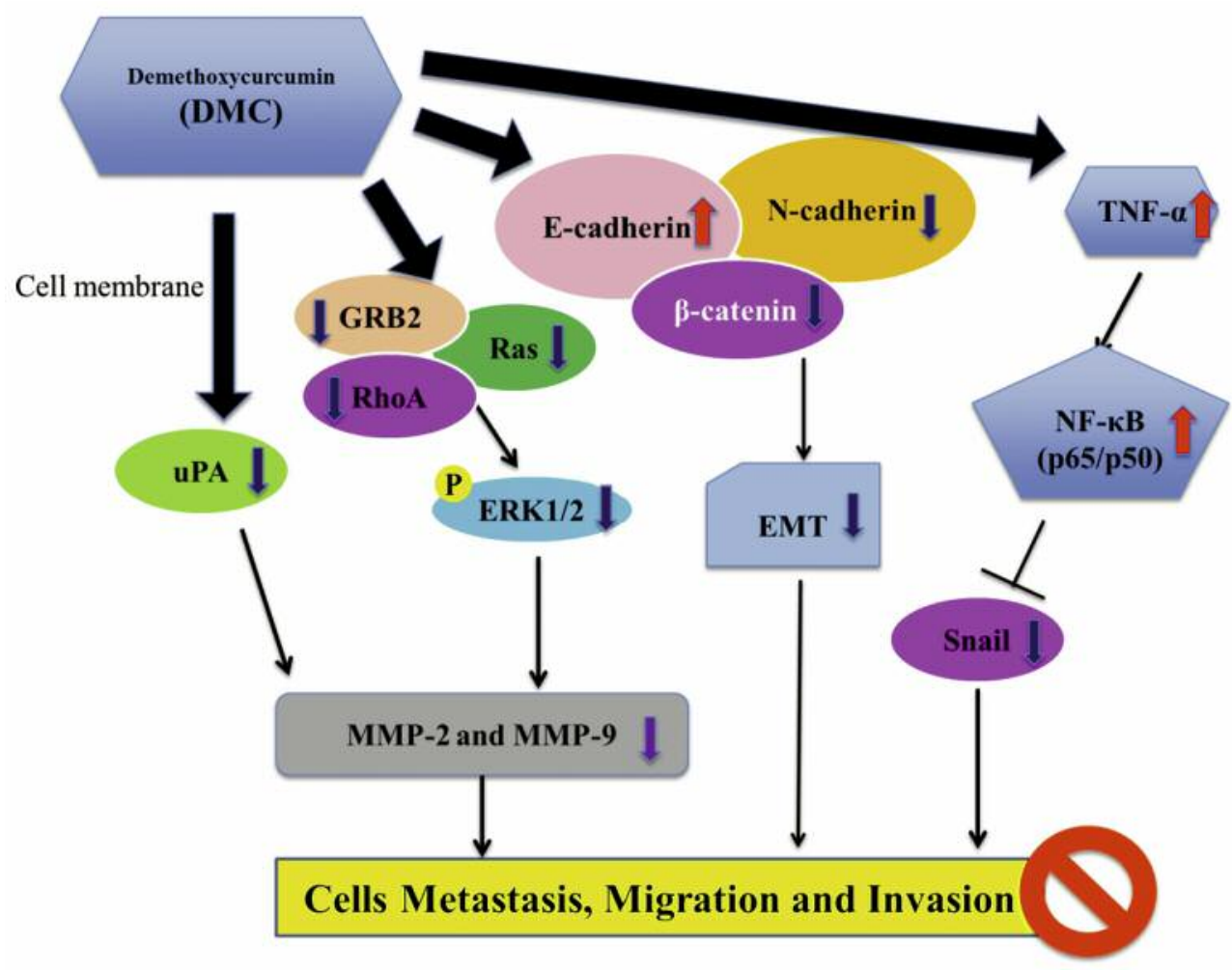

Figure 7. The possible signaling pathways for DMC inhibited cell migration and invasion in human cervical cancer HeLa cells. 


\section{Discussion}

Many studies have shown that cancer cell metastasis is a major obstacle for chemotherapy and that it involves a complex multistep process that includes cell movement, migration, invasion and angiogenesis for developing new tumor in other organs or tissues $(6,35)$. Thus, numerous studies have focused on means to inhibit cancer cell metastasis as anticancer strategy. Several studies have shown that DMC induced cancer cell death via cell cycle arrest and induction of apoptosis in many human cancer cell lines but there no reports on the effects of DMC on cell migration and invasion in human cervical cancer cells. In the present study, the effects of DMC on the migration and invasion of HeLa cells in vitro was investigated. DMC is derived from curcumin which is derived from turmeric and has been used in diet since long time ago in India and China $(16,17)$. Epidemiological evidences suggest that a diet enriched with naturally occurring substances significantly reduces the risk for many cancers (36-38).

We have investigated the cytotoxic effects of DMC on HeLa cells, and the results indicated that DMC decreased viability of HeLa cells in dose-dependently (Figure 1). Many studies have used wound healing assay for examining cancer cell mobility $(39,40)$. Using this approach, we found that DMC inhibited mobility of HeLa cells (Figure 2). Furthermore, transwell-assay was used to investigate cell migration and invasion of HeLa cells after exposure to DMC $(41,42)$. The results showed that DMC suppressed cell migration (Figure 3A) and invasion (Figure 3B). Therefore, in the present study, we focused on the molecular effects of DMC treatment on HeLa cells by examining possible alterations in the expression of several proteins related to cancer cell invasion and metastasis (43). DMC was not effective in inhibiting the gelatinolytic activity of MMP-2 and -9 at $12-48 \mathrm{~h}$ treatment (Figure 4) but inhibited MMP-2 protein expression at $12-48 \mathrm{~h}$ treatment (Figure 5B). However, DMC inhibited protein expression of MMP-2 and -9 (Figure 5B) but did not suppress the activity of MMP-2 and -9 . This may be due to other compensatory mechanisms including changes in the levels of endogenous inhibitors. MMPs are a family of zinc-dependent proteolytic enzymes that have been shown to degrade the extracellular matrix and basement membrane of cells. In particular, MMP-2 and MMP-9 are the most important enzymes for degradation of extracellular matrix $(44,45)$. Thus, MMPs have long been drug targets (46). Our results demonstrate that DMC could inhibit invasion and motility of HeLa cells by a mechanism that may not involve the down-regulation of MMP-2 and -9 activities. Futures investigations are necessary to clarify the mechanism.

Results from western blotting indicated that DMC decreased the levels of GRB2, Ras, Rho A, p-ERK1/2, ERK1/2 (Figure 5A), uPA, MMP-9, MMP-2 (Figure 5B), Snail (Figure 5C), N-cadherin, $\beta$-catenin and Vimentin
(Figure 5D), but increased the levels of TNF- $\alpha, N F-k B$ (p50), NF-kB (p65) (Figure 5C) and E-cadherin (Figure 5D) in HeLa cells. GAB2 (GRB2-associated binding protein 2) plays a critical role in the proliferation and migration of various cancers (47). MMP-2 and MMP-9 play important roles in cancer invasion and metastasis $(48,49)$. Thus, we have confirmed that DMC inhibited MMP-2 and -9 in HeLa cells. ERKs are involved in growth factor-mediated colon cancer proliferation (50). The silencing of tropomyosin related kinase B (TrKB) can suppress the activation of EMT via the downregulation of N-cadherin, Vimentin, MMP-2 and MMP-9, upregulate the E-cadherin and tissue inhibitor of metalloproteinases (TIMP-2) and to result in suppressed cell proliferation, migration and invasion (51). Our results also showed that DMC significantly increases NF-kB expression (Figure 5C) and this was also confirmed by confocal laser microscopic examination (Figure 6). NF-kB is a transcription factor which has been shown to be closely linked to cell survival, proliferation and metastasis (52) and chemical blocking of the NF-kB pathway may act as therapeutic strategy to treat the inflammation and cancer (53).

In conclusion, in the present study, DMC is shown to suppress cell mobility, migration and invasion in human cervical cancer HeLa cells through the inhibition of MMP-2 and MMP-9 signaling pathway, reduction in protein levels of GRB2, Rho A, Ras, p-ERK1/2, uPA, MMP-2, MMP-9, Ncadherin and $\beta$-catenin, and increase in the levels of $E$ cadherin and NF-kB (Figure 7). Thus, it is suggested that $\mathrm{DMC}$ is a potential candidate for developing preventive agents against human cervical cancer metastasis.

\section{Conflicts of Interest}

The Authors do not have any conflicts of interest to disclose.

\section{Acknowledgements}

This work was supported by the Grant CMUBH R103-011 from China Medical University Beigang Hospital, Yunlin, Taiwan. Experiments and data analysis were performed in part through the use of the Medical Research Core Facilities Center, Office of Research \& Development at China medical University, Taichung, Taiwan.

\section{References}

1 Ferlay J, Soerjomataram I, Dikshit R, Eser S, Mathers C, Rebelo M, Parkin DM, Forman D and Bray F: Cancer incidence and mortality worldwide: sources, methods and major patterns in GLOBOCAN 2012. Int J Cancer 136: E359-386, 2015.

2 Steenbergen RD, Snijders PJ, Heideman DA and Meijer CJ: Clinical implications of (epi)genetic changes in HPV-induced cervical precancerous lesions. Nat Rev Cancer 14: 395-405, 2014. 
3 Clamon GH, Bossler AD, Abu Hejleh $\mathrm{T}$ and Furqan M: Germline mutations predisposing to non-small cell lung cancer. Fam Cancer 14: 463-469, 2015.

4 Ministry of Health and Welfare: 2016 Statistics of Causes of Death, 2017.

5 Khazaei S, Ramachandran V, Abdul Hamid R, Mohd Esa N, Etemad A, Moradipoor S and Ismail P: Flower extract of Allium atroviolaceum triggered apoptosis, activated caspase- 3 and down-regulated antiapoptotic Bcl-2 gene in HeLa cancer cell line. Biomed Pharmacother 89: 1216-1226, 2017.

6 Gupta GP and Massague J: Cancer metastasis: building a framework. Cell 127: 679-695, 2006.

7 Kumar A, El-Osta A, Hussain AA and Marshall J: Increased sequestration of matrix metalloproteinases in ageing human Bruch's membrane: implications for ECM turnover. Invest Ophthalmol Vis Sci 51: 2664-2670, 2010.

8 Salo T, Turpeenniemi-Hujanen $\mathrm{T}$ and Tryggvason K: Tumorpromoting phorbol esters and cell proliferation stimulate secretion of basement membrane (type IV) collagen-degrading metalloproteinase by human fibroblasts. J Biol Chem 260: 8526$8531,1985$.

9 Kallakury BV, Karikehalli S, Haholu A, Sheehan CE, Azumi N and Ross JS: Increased expression of matrix metalloproteinases 2 and 9 and tissue inhibitors of metalloproteinases 1 and 2 correlate with poor prognostic variables in renal cell carcinoma. Clin Cancer Res 7: 3113-3119, 2001.

10 Yoshizaki T, Maruyama Y, Sato H and Furukawa M: Expression of tissue inhibitor of matrix metalloproteinase- 2 correlates with activation of matrix metalloproteinase- 2 and predicts poor prognosis in tongue squamous cell carcinoma. Int J Cancer 95: 44-50, 2001.

11 Silbergeld DL and Chicoine MR: Isolation and characterization of human malignant glioma cells from histologically normal brain. J Neurosurg 86: 525-531, 1997.

12 Chan-Hui PY and Weaver R: Human mitogen-activated protein kinase kinase kinase mediates the stress-induced activation of mitogen-activated protein kinase cascades. Biochem J 336(Pt 3): 599-609, 1998.

13 Sliva D: Signaling pathways responsible for cancer cell invasion as targets for cancer therapy. Curr Cancer Drug Targets 4: 327336, 2004.

14 Rose P, Huang Q, Ong CN and Whiteman M: Broccoli and watercress suppress matrix metalloproteinase-9 activity and invasiveness of human MDA-MB-231 breast cancer cells. Toxicol Appl Pharmacol 209: 105-113, 2005.

15 Lee WJ, Chen WK, Wang CJ, Lin WL and Tseng TH: Apigenin inhibits HGF-promoted invasive growth and metastasis involving blocking PI3K/Akt pathway and beta 4 integrin function in MDA-MB-231 breast cancer cells. Toxicol Appl Pharmacol 226: 178-191, 2008.

16 Jayaprakasha GK, Jagan Mohan Rao L and Sakariah KK: Chemistry and biological activities of C. longa. Trends Food Sci Technol 16: 533-548, 2005.

17 Hatcher H, Planalp R, Cho J, Torti FM and Torti SV: Curcumin: from ancient medicine to current clinical trials. Cell Mol Life Sci 65: 1631-1652, 2008.

18 Tamvakopoulos C, Dimas K, Sofianos ZD, Hatziantoniou S, Han Z, Liu ZL, Wyche JH and Pantazis P: Metabolism and anticancer activity of the curcumin analogue, dimethoxycurcumin. Clin Cancer Res 13: 1269-1277, 2007.
19 Ni X, Zhang A, Zhao Z, Shen Y and Wang S: Demethoxycurcumin inhibits cell proliferation, migration and invasion in prostate cancer cells. Oncol Rep 28: 85-90, 2012.

20 Ko YC, Lien JC, Liu HC, Hsu SC, Ji BC, Yang MD, Hsu WH and Chung JG: Demethoxycurcumin induces the apoptosis of human lung cancer NCI-H460 cells through the mitochondrialdependent pathway. Oncol Rep 33: 2429-2437, 2015.

21 Xin Y, Huang Q, Zhang P, Guo WW, Zhang LZ and Jiang G: Demethoxycurcumin in combination with ultraviolet radiation $\mathrm{B}$ induces apoptosis through the mitochondrial pathway and caspase activation in A431 and HaCaT cells. Tumour Biol 39: 1010428317706216, 2017.

22 Kim DS, Park SY and Kim JK: Curcuminoids from Curcuma longa L. (Zingiberaceae) that protect $\mathrm{PC} 12$ rat pheochromocytoma and normal human umbilical vein endothelial cells from betaA(142) insult. Neurosci Lett 303: 57-61, 2001.

23 Sandur SK, Pandey MK, Sung B, Ahn KS, Murakami A, Sethi G, Limtrakul P, Badmaev V and Aggarwal BB: Curcumin, demethoxycurcumin, bisdemethoxycurcumin, tetrahydrocurcumin and turmerones differentially regulate anti-inflammatory and antiproliferative responses through a ROS-independent mechanism. Carcinogenesis 28: 1765-1773, 2007.

24 Zhang JS, Li DM, Ma Y, He N, Gu Q, Wang FS, Jiang SQ, Chen BQ and Liu JR: gamma-Tocotrienol induces paraptosis-like cell death in human colon carcinoma SW620 cells. PLoS One 8: e57779, 2013.

25 Chang YM, Velmurugan BK, Kuo WW, Chen YS, Ho TJ, Tsai CT, Ye CX, Tsai CH, Tsai FJ and Huang CY: Inhibitory effect of alpinate Oxyphyllae fructus extracts on Ang II-induced cardiac pathological remodeling-related pathways in $\mathrm{H} 9 \mathrm{c} 2$ cardiomyoblast cells. BioMedicine 3: 148-152, 2013.

26 Chiu YJ, Hour MJ, Lu CC, Chung JG, Kuo SC, Huang WW, Chen HJ, Jin YA and Yang JS: Novel quinazoline HMJ-30 induces U-2 OS human osteogenic sarcoma cell apoptosis through induction of oxidative stress and up-regulation of ATM/p53 signaling pathway. J Orthop Res 29: 1448-1456, 2011.

27 Huang WW, Chiu YJ, Fan MJ, Lu HF, Yeh HF, Li KH, Chen PY, Chung JG and Yang JS: Kaempferol induced apoptosis via endoplasmic reticulum stress and mitochondria-dependent pathway in human osteosarcoma U-2 OS cells. Mol Nutr Food Res 54: 1585-1595, 2010.

28 Lai KC, Hsu SC, Yang JS, Yu CC, Lein JC and Chung JG: Diallyl trisulfide inhibits migration, invasion and angiogenesis of human colon cancer HT-29 cells and umbilical vein endothelial cells, and suppresses murine xenograft tumour growth. J Cell Mol Med 19: 474-484, 2015.

29 Lin MC, Tsai SY, Wang FY, Liu FH, Syu JN and Tang FY: Leptin induces cell invasion and the upregulation of matrilysin in human colon cancer cells. BioMedicine 3: 174-180, 2013.

30 Chan CY, Lien CH, Lee MF and Huang CY: Quercetin suppresses cellular migration and invasion in human head and neck squamous cell carcinoma (HNSCC). Biomedicine (Taipei) 6: 15, 2016.

$31 \mathrm{Wu}$ KC, Yang ST, Hsia TC, Yang JS, Chiou SM, Lu CC, Wu RS and Chung JG: Suppression of cell invasion and migration by propofol are involved in down-regulating matrix metalloproteinase-2 and p38 MAPK signaling in A549 human lung adenocarcinoma epithelial cells. Anticancer Res 32: 48334842, 2012. 
32 Lin SS, Lai KC, Hsu SC, Yang JS, Kuo CL, Lin JP, Ma YS, Wu $\mathrm{CC}$ and Chung JG: Curcumin inhibits the migration and invasion of human A549 lung cancer cells through the inhibition of matrix metalloproteinase-2 and -9 and Vascular Endothelial Growth Factor (VEGF). Cancer Lett 285: 127-133, 2009.

33 Wu SH, Hsiao YT, Kuo CL, Yu FS, Hsu SC, Wu PP, Chen JC, Hsia TC, Liu HC, Hsu WH and Chung JG: Bufalin Inhibits NCIH460 Human Lung Cancer Cell Metastasis In Vitro by Inhibiting MAPKs, MMPs, and NF-kappaB Pathways. Am J Chin Med 43: 1247-1264, 2015

34 Lin YJ, Ho TJ, Lin TH, Hsu WY, Huang SM, Liao CC, Lai CH, Liu X, Tsang H, Lai CC and Tsai FJ: P-coumaric acid regulates exon 12 splicing of the ATP7B gene by modulating hnRNP A1 protein expressions. BioMedicine 5: 1-9, 2015.

35 Huang YL, Chu YL, Ho CT, Chung JG, Lai CI, Su YC, Kuo YH and Sheen LY: Antcin K, an active triterpenoid from the fruiting bodies of basswood-cultivated antrodia cinnamomea, inhibits metastasis via suppression of integrin-mediated adhesion, migration, and invasion in human hepatoma cells. J Agric Food Chem 63: 4561-4569, 2015.

36 Chien CS, Shen KH, Huang JS, Ko SC and Shih YW: Antimetastatic potential of fisetin involves inactivation of the $\mathrm{PI} 3 \mathrm{~K} / \mathrm{Akt}$ and JNK signaling pathways with downregulation of MMP-2/9 expressions in prostate cancer PC-3 cells. Mol Cell Biochem 333: 169-180, 2010.

37 Reuben SC, Gopalan A, Petit DM and Bishayee A: Modulation of angiogenesis by dietary phytoconstituents in the prevention and intervention of breast cancer. Mol Nutr Food Res 56: 14-29, 2012.

38 Sato F, Matsukawa Y, Matsumoto K, Nishino H and Sakai T: Apigenin induces morphological differentiation and $\mathrm{G}_{2}-\mathrm{M}$ arrest in rat neuronal cells. Biochem Biophys Res Commun 204: 578584, 1994.

39 Park SJ, Kong HK, Kim YS, Lee YS and Park JH: Inhibition of S-adenosylhomocysteine hydrolase decreases cell mobility and cell proliferation through cell cycle arrest. Am J Cancer Res 5: 2127-2138, 2015.

$40 \mathrm{Wu}$ ZY, Lien JC, Huang YP, Liao CL, Lin JJ, Fan MJ, Ko YC, Hsiao YP, Lu HF and Chung JG: Casticin inhibits A375.S2 human melanoma cell migration/invasion through downregulating NF-kappaB and matrix metalloproteinase-2 and -1 . Molecules 21: 384, 2016.

41 Ji BC, Hsiao YP, Tsai CH, Chang SJ, Hsu SC, Liu HC, Huang YP, Lien JC and Chung JG: Cantharidin impairs cell migration and invasion of A375.S2 human melanoma cells by suppressing MMP-2 and -9 through PI3K/NF-kappaB signaling pathways. Anticancer Res 35: 729-738, 2015.

42 Liao CL, Lai KC, Huang AC, Yang JS, Lin JJ, Wu SH, Gibson Wood W, Lin JG and Chung JG: Gallic acid inhibits migration and invasion in human osteosarcoma U-2 OS cells through suppressing the matrix metalloproteinase-2/-9, protein kinase $\mathrm{B}$ (PKB) and PKC signaling pathways. Food Chem Toxicol 50: 1734-1740, 2012.
43 Chen HW, Lee JY, Huang JY, Wang CC, Chen WJ, Su SF, Huang CW, Ho CC, Chen JJ, Tsai MF, Yu SL and Yang PC: Curcumin inhibits lung cancer cell invasion and metastasis through the tumor suppressor HLJ1. Cancer Res 68: 7428-7438, 2008.

44 Nair S, Phillips AO, Norton N, Spurlock G, Williams HJ, Craig KJ, Williams JD, Williams NM and Bowen T: Further evidence for the association of MMP9 with nephropathy in type 2 diabetes and application of DNA pooling technology to candidate gene screening. J Nephrol 21: 400-405, 2008.

45 Liu Z, Li L, Yang Z, Luo W, Li X, Yang H, Yao K, Wu B and Fang W: Increased expression of MMP9 is correlated with poor prognosis of nasopharyngeal carcinoma. BMC Cancer 10: 270, 2010.

46 Bauvois B: New facets of matrix metalloproteinases MMP-2 and MMP-9 as cell surface transducers: outside-in signaling and relationship to tumor progression. Biochim Biophys Acta 1825: 29-36, 2012.

47 Matsumura T, Sugimachi K, Takahashi Y, Uchi R, Sawada G, Ueda M, Hirata H, Sakimura S, Ueo H, Takano Y, Kurashige J, Shinden Y, Eguchi H, Sudo T, Yamamoto H, Doki Y, Mori M and Mimori K: Clinical significance of GAB2, a scaffolding/ docking protein acting downstream of EGFR in human colorectal cancer. Ann Surg Oncol 21(Suppl 4): S743-749, 2014.

48 Birkedal-Hansen H, Moore WG, Bodden MK, Windsor LJ, Birkedal-Hansen B, DeCarlo A and Engler JA: Matrix metalloproteinases: a review. Crit Rev Oral Biol Med 4: 197-250, 1993.

49 Dutta A, Li J, Lu H, Akech J, Pratap J, Wang T, Zerlanko BJ, FitzGerald TJ, Jiang Z, Birbe R, Wixted J, Violette SM, Stein JL, Stein GS, Lian JB and Languino LR: Integrin alphavbeta6 promotes an osteolytic program in cancer cells by upregulating MMP2. Cancer Res 74: 1598-1608, 2014.

50 Waseem T, Duxbury M, Ashley SW and Robinson MK: Ghrelin promotes intestinal epithelial cell proliferation through PI3K/Akt pathway and EGFR trans-activation both converging to ERK 1/2 phosphorylation. Peptides 52: 113-121, 2014.

51 Yuan Y, Ye HQ and Ren QC: Upregulation of the BDNF/TrKB pathway promotes epithelial-mesenchymal transition, as well as the migration and invasion of cervical cancer. Int J Oncol 52: 461-472, 2018.

52 Guttridge DC, Albanese C, Reuther JY, Pestell RG and Baldwin AS Jr.: NF-kappaB controls cell growth and differentiation through transcriptional regulation of cyclin D1. Mol Cell Biol 19: 5785-5799, 1999.

53 Yamamoto Y and Gaynor RB: Therapeutic potential of inhibition of the NF-kappaB pathway in the treatment of inflammation and cancer. J Clin Invest 107: 135-142, 2001.

Received March 19, 2018

Revised April 3, 2018

Accepted April 10, 2018 